\title{
EFEKTIFITAS EKSTRAK DAUN KELOR (Moringa oleifera lam) DALAM MEMPERBAIKI PROFIL SERUM IRON, SATURASI TRANSFERIN, DAN TOTAL IRON BINDING CAPACITY TIKUS PUTIH JANTAN DIET RENDAH ZAT BESI
}

\author{
Diah Hermayanti ${ }^{1}$, Fathiyah Syafitri ${ }^{2}$ \\ ${ }^{1}$ Fakultas kedokteran Universitas Muhammadiyah Malang \\ ${ }^{2}$ Fakultas kedokteran Universitas Muhammadiyah Malang
}

Email: diahhermayanti_umm@yahoo.com

\begin{abstract}
Background: Iron deficiency can cause anemia which affects health and work productivity. Moringa leaves contain a lot of iron and vitamin $\mathrm{C}$, are thought to increase serum iron levels, transferrin saturation, and improve total iron binding capacity. Objectives: To determine the effectiveness of Moringa oleifera lam. Leaf extract on serum iron levels, transferrin saturation, and total iron binding capacity in white rats (Rattus Novergicus Strain Wistar) given a diet low in iron (Fe). Materials and methods: true experimental research using post test only control group design. The object of this study was thirty male white mice (Rattus novergicus Strain wistar) who were given a low iron diet. The study was divided into negative control groups, positive controls, treatment groups with a dose of Moringa leaf extract $400 \mathrm{mg} / \mathrm{kg} \mathrm{BW}, 800 \mathrm{mg} / \mathrm{kg} \mathrm{BW}, 1,600 \mathrm{mg} / \mathrm{kg} \mathrm{BW}$, and the ferro fumaras control group (FF) $175 \mathrm{mg} / 200$ BB. Results: Multivariate Manova serum iron 0.001 ( $p<0.05)$, TIBC 0.19 ( $p>0.05$ ), and transferrin saturation 0.001 $(\mathrm{p}<0.05)$. In the Post Hoc Tukey test the mean serum iron and transferrin saturation appeared to differ significantly in the negative control group with all the other treatment groups, but did not show a significant difference between the positive control group, FF group, and the treatment group. Conclusion: The administration of Moringa leaf extract was less significant in improving serum iron levels, transferrin saturation, and total iron binding capacity of male white mice induced by a low iron diet.
\end{abstract}

Keywords : iron deficiency, anemia, serum iron, transfferin saturation, total iron binding capacity

\section{ABSTRAK}

Latar belakang : Defisiensi zat besi dapat menyebabkan anemia yang berdampak pada kesehatan dan produktivitas kerja. Daun kelor mengandung banyak zat besi dan vitamin $\mathrm{C}$, diduga dapat meningkatkan kadar serum iron , saturasi transferin, dan memperbaiki total iron binding capacity. Tujuan penelitian : mengetahui efektivitas pemberian ekstrak daun kelor (Moringa oleifera lam.) terhadap kadar serum iron, saturasi transferin, dan total iron binding capacity pada tikus putih (Rattus Novergicus Strain Wistar) yang diberi diet rendah zat besi (Fe). Metodologi penelitian : penelitian true experimental menggunakan post test only control group design. Obyek penelitian ini adalah tikus putih jantan (Rattus novergicus Strain wistar) yang diberi diet rendah besi. Penelitian terbagi dalam kelompok kontrol negatif, kontrol positif, kelompok perlakuan dengan dosis ekstrak daun kelor 400 $\mathrm{mg} / \mathrm{kg} \mathrm{BB}, 800 \mathrm{mg} / \mathrm{kg} \mathrm{BB}, 1.600 \mathrm{mg} / \mathrm{kg} \mathrm{BB}$, dan kelompok kontrol ferro fumaras (FF) $175 \mathrm{mg} / 200 \mathrm{BB}$.

Hasil penelitian : Uji multivariate Manova serum iron 0,001 $(\mathrm{p}<0,05)$, TIBC $0,19(\mathrm{p}>0,05)$, dan saturasi transferin $0,001(\mathrm{p}<0,05)$. Pada uji Post Hoc Tukey rerata serum iron dan saturasi transferin tampak berbeda bermakna pada kelompok kontrol negatif dengan semua kelompok perlakuan lainnya, namun tidak menunjukkan perbedaan yang bermakna antara kelompok kontrol positif, kelompok FF, maupun kelompok perlakuan. Kesimpulan : Pemberian ekstrak daun kelor kurang bermakna dalam memperbaiki kadar serum iron, saturasi transferin, dan total iron binding capacity tikus putih jantan yang diinduksi diet rendah besi.

Kata kunci : defisiensi besi, anemia, serum iron, saturasi transferin, total iron binding capacity 


\section{PENDAHULUAN}

Anemia masih menjadi masalah kesehatan dunia dan terutama negara sedang berkembang. Di dunia, prevalensi anemia tertinggi menyerang anak-anak sebesar $42,6 \%$ dan pada wanita hamil sebesar $38,2 \%$. Pemberian suplemen zat besi dapat mengeliminasi kasus anemia sekitar $42 \%$ pada anak, dan $50 \%$ pada wanita ${ }^{1}$.

Di Indonesia, menurut laporan dari Riset Kesehatan Dasar (Riskesdas) pada tahun 2013, prevalensi kejadian anemia pada umur $\geq 1$ tahun adalah 27,1 \%. Berdasarkan golongan umur didapatkan bahwa anemia pada balita cukup tinggi yaitu $28,1 \%$, dan wanita hamil sekitar $37,1 \%{ }^{2}$. Kelompok risiko tinggi seperti balita, kehamilan dan masa laktasi; masyarakat dengan status sosioekonomi yang rendah terkait dengan asupan diet zat besi, orang yang sedang mengalami infeksi dan malabsorbsi, berpotensi mengalami kejadian anemia defisiensi. ${ }^{3}$

Indikator pada anemia defisiensi besi, yaitu penurunan kadar serum iron dan saturasi transferin, serta terjadi peningkatan total iron binding capacity (TIBC) ${ }^{4,5}$. Apabila serum iron dan cadangan zat besi dalam tubuh telah menurun maka akan terjadi gangguan pembentukan sel eritrosit sehingga timbullah kondisi anemia. ${ }^{6,7,8}$.

Daun kelor (Moringa oleifera lam) mengandung kadar mineral zat besi yang tinggi sebesar $32,5 \mathrm{mg}$ per 100 gram, vitamin $\mathrm{A}$, dan vitamin $\mathrm{C} 9$. Penelitian ini bertujuan untuk mengetahui efektifitas daun kelor dalam meningkatkan serum iron, saturasi transferrin dan perbaikan total iron binding capacity pada tikus jantan yang diberi diet rendah zat besi.

\section{BAHAN DAN METODE}

\section{Ekstrak daun kelor}

Ekstrak etanol daun kelor (Moringa oleifera lam.) diperoleh dari Materia Medica Batu yang telah dideterminasi. Ekstrak daun kelor dibuat dalam bentuk cairan yang dilarutkan dengan etanol $70 \%$.

\section{Disain penelitian}

Penelitian dilakukan pada 30 ekor tikus jantan putih strain wistar yang dibagi dalam enam kelompok. Masing masing kelompok menjalani masa adaptasi 1 minggu dan mendapat pakan dan minum standar, berikutnya pada kelompok kontrol positif, kelompok kontrol obat, dan kelompok perlakuan diinduksi diet rendah besi selama 1 minggu. Berikutnya mendapat kelompok obat mendapat ferro fumaras dan kelompok perlakuan mendapat ekstrak adun kelor selama 1 minggu. Pembagian kelompok sebagai berikut :

- kelompok kontrol negatif

- kelompok kontrol positif

- kelompok obat ferro fumaras $175 \mathrm{mg} / 200 \mathrm{gr}$ BB

- kelompok perlakuan dengan dosis ekstrak daun kelor $400 \mathrm{mg} / \mathrm{kgbb}$

- kelompok perlakuan dengan dosis ekstrak daun kelor $800 \mathrm{mg} / \mathrm{kgbb}$

- kelompok perlakuan dengan dosis ekstrak daun kelor $1.600 \mathrm{mg} / \mathrm{kgbb}$.

\section{Induksi anemia}

Induksi anemia dilakukan dengan memberikan pakan rendah zat besi dengan komposisi protein 20.3 gram, karbohidrat 63.9 gram, lemak 7 gram, kasein 200 gram, tepung maizena 397,5 gram, sukrosa 100 gram, minyak kedelai 70 gram, mineral mix (tanpa zat besi) 35 gram. Semua bahan diblender hingga rata ${ }^{10}$.

\section{Pengukuran parameter}

Srum iron, saturasi transferrin dan total iron binding capacity diukur dengan metode spektrofotometer menggunkan alat Cobas C 311. Kadar haemoglobin diukur dengan alat autoanalyzer Sysmex.

\section{Analisis statistik}

Data penelitian diuji normalitas dan homogenitasnya, kemudian dilakukan uji Manova, dan uji post Hoc Bonferroni.

\section{HASIL PENELITIAN DAN DISKUSI}

Hasil penelitian Efektivitas Ekstrak Daun Kelor (Moringa oleifera) dalam memperbaiki profil serum iron dan tota iron binding capacity (TIBC) pada tikus putih jantan defisiensi besi menunjukkan peningkatan kadar hemoglobin pada kelompok PI, PII, dan PIII. Kadar serum iron pada kelompok P II dan P III meningkat dibanding dengan kelompok kontrol positif namun masih di bawah kelompok yang mendapat ferro fumaras (FF). TIBC meningkat pada kelompok kontrol positif, P I, P II, dan P III dibanding dengan kelompok kontrol negatif dan FF. Saturasi transferrin pada kelompok perlakuan sedikit meningkat dibanding dengan kelompok kontrol positif, namun di bawah kelompok kontrol negatf dan FF. 
Tabel 1. Rerata kadar hemoglobin, serum iron, TIBC, dan saturasi transferrin

\begin{tabular}{|c|c|c|c|c|c|c|c|c|}
\hline \multirow[t]{2}{*}{ Kelompok } & \multicolumn{2}{|c|}{ Hemoglobin } & \multicolumn{2}{|c|}{ Serum Iron } & \multicolumn{2}{|l|}{ TIBC } & \multicolumn{2}{|c|}{$\begin{array}{c}\text { Saturasi } \\
\text { transferin }\end{array}$} \\
\hline & Rerata & SD & Rerata & SD & Rerata & SD & Rerata & SD \\
\hline $\mathrm{K}-$ & 14,13 & 0,57 & 289,75 & 40,94 & 534,00 & 72,18 & 55,75 & 14,93 \\
\hline $\mathrm{K}+$ & 14,03 & 0,81 & 155,25 & 12,84 & 648,50 & 105,42 & 24,50 & 3,11 \\
\hline $\mathrm{FF}$ & 13,95 & 0,88 & 187,50 & 47,93 & 549,50 & 81,34 & 34,75 & 10,86 \\
\hline P I & 14,45 & 0,30 & 165,50 & 13,96 & 636,75 & 92,66 & 26,25 & 4,11 \\
\hline P II & 14,57 & 1,44 & 170,00 & 53,18 & 655,75 & 83,39 & 26,52 & 10,24 \\
\hline P III & 14,64 & 0,70 & 159,50 & 36,41 & 657,25 & 79,46 & 25,00 & 6,88 \\
\hline
\end{tabular}

Keterangan :

K- $\quad$ : Kelompok kontrol negatif

$\mathrm{K}+\quad$ : Kelompok kontrol positif

FF : Kelompok ferro fumaras

PI : Kelompok ekstrak daun kelor dosis 400 $\mathrm{mg} / \mathrm{kg} \mathrm{BB}$

PII : Kelompok ekstrak daun kelor dosis 800 $\mathrm{mg} / \mathrm{kg} \mathrm{BB}$

PIII : Kelompok ekstrak daun kelor dosis 1.600 $\mathrm{mg} / \mathrm{kg} \mathrm{BB}$

Tabel 2. Kadar Hemoglobin Pada Kelompok Perlakuan

\section{Kadar Hemoglobin}

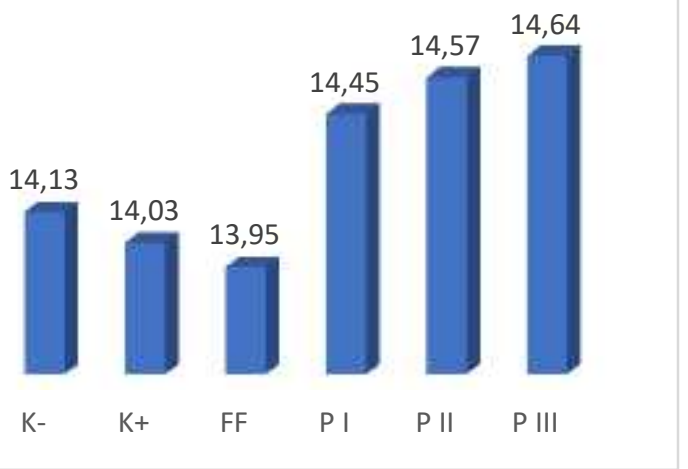

Tabel 3. Kadar Serum Iron Pada Kelompok Perlakuan

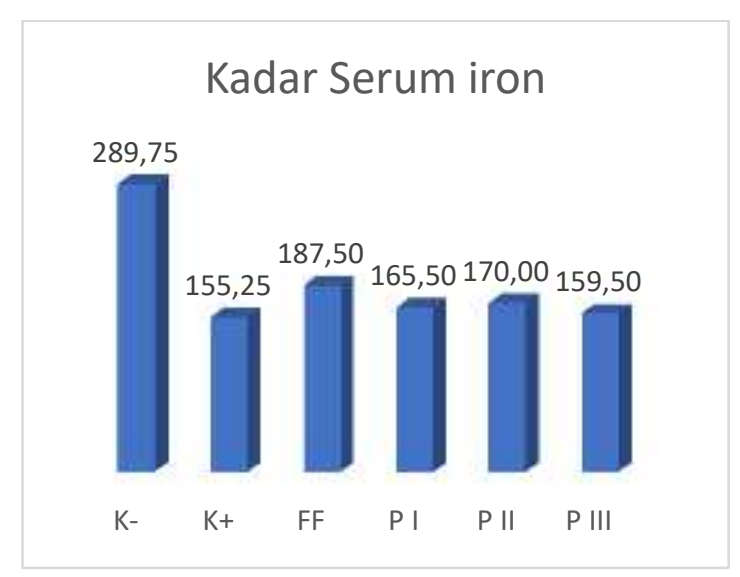

Tabel 4. Total Iron Binding Capacity (TIBC) Pada Kelompok Perlakuan

\section{Total Iron Binding Capacity}

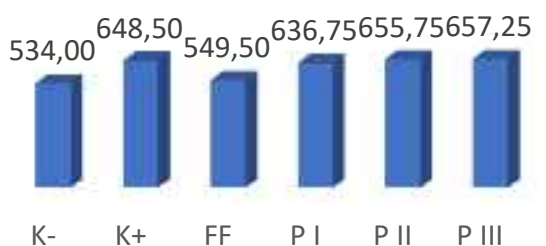


Tabel 5. Kadar Saturasi Transferin Pada Kelompok Perlakuan

\section{Saturasi Transferin}

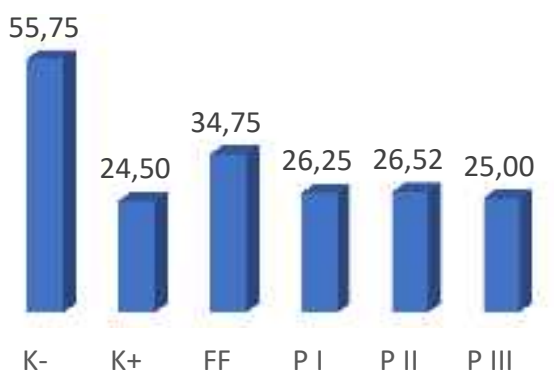

Berdasarkan data yang telah diperoleh kemudian dilakukan uji normalitas dan homogenitas data. Hasil uji normalitas menunjukkan bahwa pada kolom uji Shapiro-Wilk nilai Sig Hemoglobin 0,4 (p $>0,05)$, serum iron 0,05 , TIBC $0,5(\mathrm{p}>0,05)$, dan serum transferin $0,001 \quad(p<0,05)$. Uji homogenitas untuk hemoglobin $0,85(p>0,05)$, serum iron $1,00(p>0,05)$, TIBC 0,38 ( $>0,05)$, dan saturasi transferin 1,00 ( $>00,05)$. Karena data terdistribusi normal dan homogeny selanjutnya dilakukan uji multivariate Manova, untuk hemoglobin 0,78 ( $\mathrm{p}>0,05)$, serum iron $0,001(\mathrm{p}<0,05)$, TIBC $0,19(\mathrm{p}>0,05)$, dan saturasi transferin $0,001(\mathrm{p}<0,05)$.

Selanjutnya dilakukan uji beda rerata antar kelompok menggunakan Post Hoc Tukey. Rerata hemoglobin dan TIBC tampak tidak berbeda bermakna pada masing-masing kelompok. Rerata serum iron dan saturasi transferin tampak berbeda bermakna pada kelompok kontrol negatif dengan semua kelompok perlakuan lainnya, namun tidak menunjukkan perbedaan yang bermakna pada kelompok kontrol positif dengan kelompok FF, P I, P II , dan P III.

Berdasarkan hasil data penelitian dijumpai peningkatan kadar hemoglobin pada kelompok tikus yang mendapatkan ekstrak daun kelor, tertinggi pada kelompok P III. Namun demikian secara statistik tidak dijumpai perbedaan yang bermakna $(p>0,05)$. Secara fisiologis akan terjadi anemia apa bila cadangan besi tubuh sudah tidak dapat memberikan persediaan zat besinya untuk eritropoisis. Selama masih terdapat cadangan zat besi, belum terjadi keadaan anemia. Pada penelitian ini nampaknya perlakuan induksi pakan rendah zat besi dengan komposisi mineral mix tanpa zat besi selama 21 hari belum menampakkan penurunan pada kadar hemoglobin. Namun demikian induksi pakan rendah zat besi ini telah dapat menurunkan secara bermakna kadar serum iron dan saturasi transferin pada kelompok perlakuan. Serum iron dan saturasi transferin terendah pada kelompok kontrol positif, meningkat pada ketiga kelompok yang mendapatkan ekstrak daun kelor dan tertinggi kadarnya pada kelompok yang mendapatkan ferro fumaras. Namun demikian secara statistik belum menunjukkan perbedaan yang bermakna antar kelompok perlakuan. Kemungkinan serum iron telah menurun dan iron terpakai untuk mengisi kebutuhan cadangan zat besi dan untuk pembentukan sel eritrosit. Ekstrak daun kelor belum secara bermakna dapat meningkatkan serum iron dan saturasi transferin.

Total iron binding capacity (TIBC) terendah pada kelompok kontrol negatif dan kelompok ferro fumaras. Kemudian meningkat pada kelompok kontrol positif dan semua kelompok yang mendapatkan ekstrak daun kelor, namun tidak berbeda bermakna pada masing-masing kelompok. TIBC menunjukkan pengukuran konsentrasi besi maksimal yang dapat diikat oleh transferin. Pada anemia defisiensi besi TIBC akan meningkat, yang menggambarkan kemampuan transferin mengikat zat besi dari luar. ${ }^{11}$.

Penelitian ini tidak sejalan dengan penelitian yang dilakukan oleh Osman $\mathrm{HM}^{12}$, dimana terdapat peningkatan signifikan kadar hemoglobin pada tikus putih albino yang diinduksi dengan aluminium $\left(\mathrm{AlCl}_{3}\right)$ dan diberikan ekstraks daun kelor $300 \mathrm{mg} / \mathrm{kg}$ selama 21 hari. Penelitian juga tidak sejalan dengan penelitian yang dilakukan oleh Mun'im et al. pada tikus putih yang diinduksi anilin $\left(\mathrm{AlCl}_{3}\right)$ dan mendapatkan ekstrak daun kelor. Pada penelitian tersebut dosis ekstrak daun kelor 792 mg/200 bw meningkatkan kadar hemoglobin dan jumlah sel eritrosit secara bermakna. Dilaporkan juga terjadi peningkatan pada hematocrit dan kadar total iron. Anilin menginduksi anemia dengan mekanisme oksidasi hemoglobin oleh metabolitnya fenilhidroksilamin menjadi methemoglobin dan peroksida hidrogen yang menginduksi hemolitik, sehingga keadaan anemia tercapai dalam waktu yang singkat. ${ }^{13}$

Kadar zat besi yang tinggi pada ekstrak daun kelor, namun pada penelitian ini belum dapat meningkatkan serum iron, kemungkinan dapat dipengaruhi oleh sifat bioavailabilitas zat besi dalam penyerapan. Zat besi yang berasal dari makanan hanya sekitar 10\% yang diabsoprsi. Absoprsi besi sendiri merupakan proses kompleks yang terjadi di duodenum dan jejunum bagian proksimal. Pada brush border dari enterosit, terdapat beberapa protein pengangkut zat besi dan jalur absoprsi spesifik untuk dua bentuk ion $\left(\mathrm{Fe}^{2+}\right.$ dan $\mathrm{Fe}^{3+}$, keduanya berasal dari molekul besi nonheme), dan untuk molekul heme (besi heme). Besi nonheme berhubungan dengan berbagai cadangan protein termasuk ferritin, sedangkan besi heme berada dalam hemoprotein seperti Mb DAN Hb. Pada PH asam di lambung, heme terurai dari hemoproteinn, sedangkan besi non-heme stabil dalam bentuk tereduksi ( $\mathrm{Fe} 2+$ ). Besi non-heme ditangkap, namun beberapa kompleks yang dapat mempengaruhi absopsinya seperti plant derived phytates atau tannin. Ascorbic acid dan 
komponen asam lainnya yang berasal dari diet dapat meningkatkan absoprsi zat besi. ${ }^{14}$ (Abramowski SW, 2014). Penelitian oleh Gallaher $(2017)^{15}$ tentang bioavailabilitas besi ekstrak daun kelor pada makanan yang biasa dikonsumsi oleh orang Uganda menduga bahwa pemberian daun kelor tidak berhasil memperbaiki status besi, sebagai akibat tingginya kadar phytic acid yang dapat mengikat zat besi sehingga tidak dapat diabsoprsi.

Lama waktu pemberian terapi zat besi pada anemia defisiensi besi minimal sekitar 3 bulan setelah kadar hemoglobin terkoreksi. Lama waktu pemberian ini bertujuan untuk mengisi cadangan besi. Efektifitas pemberian terapi besi ini dipantau dengan memeriksa status besi pasien. ${ }^{16}$. Pada penelitian ini waktu pemberian ekstrak daun kelor sekitar 12 hari, kemungkinan waktu pemberian kurang lama, sehingga belum cukup untuk mengisi cadangan besi.

\section{SIMPULAN DAN SARAN}

Pada penelitian ini ekstrak daun kelor meningkatkan kadar hemoglobin, serum iron, saturasi tarnsferin, dan menurunkan total iron binding capacity namun kurang bermakna. Diduga waktu induksi anemia yang kurang, serta kurangnya bioavailabitis besi mempengaruhi hasil penelitian. Disarankan penelitian dengan merubah tehnik induksi dan metode meningkatkan bioavailabilitas besi pada ekstrak daun kelor.

\section{DAFTAR PUSTAKA}

1. WHO, 2015, The Global Prevalence of Anemia in 2011, WHO Document Production Services, Geneva, Switzerland

2. Riskesdas, 2013, Riset Kesehatan Dasar, Badan Penelitian dan Pengembangan Kesehatan, Kementerian Kesehatan RI Tahun 2013, http://www.depkes.go.id/resources/download/gen eral/Hasi1\%20Riskesdas\%202013.pdf

3. Parmar BJ, Jwal Doctor, Ruhi, et al. 2017. Iron Definition : Beyond Anemia. Academic Journal of Pediatrics and Neonatology.Vol 2.

4. Devkota BP, 2014, Iron, Medscape, http://emedicine.medscape.com/article/2085704overview

5. Jimenez K, Dabsch SK, Gasche C, 2015, Gastroenterol Hepatol 11(4):241-250, https://www.ncbi.nlm.nih.gov/pmc/articles/PMC4 836595/

6. Goodnough LT, Nemeth E, 2014, Iron Deficiency and Related Disorders, Wintrobe's Clinical Hematology 13 th eds, Greer JP Ed, Lippincott Williams \& Wilkins, Philadelphia, pp.617-42

7. Harper JL, 2016, Iron Deficiency Anemia Treatment \& Management, Medscape, http://emedicine.medscape.com/article/202333treatment

8. Adamson JW. 2015. Iron Deficiency and Other Hypoproliferative Anemias. In: Kasper DL, Hauser SL, Jameson JL, et al (eds). Harrison's Principles of Internal Medicine. 19 eds. McGrawHill Education. USA. pp.625 - 630

9. Kathryn A. 2011. The Nutrient Content of Moringa Oleifera Leaves. Educational Concerns for Hunger Organization.

10. Ibarra AM, Huerta M, Hernandez SV, et all, 2016, The Effect of Dietary Iron and Capsaicin on Hemoglobin, Blood Glucose, Insulin Tolerance, Cholesterol, and Triglycerides, in Healthy and Diabetic Wistar Rats, Plos One/DOI : :10.1371/journal.pone.0152625 https://www.ncbi.nlm.nih.gov/pubmed/27064411

11. Devkota BP, 2014, Iron Binding Capacity, Medscape,

http://emedicine.medscape.com/article/2085726overview

12. Osman HM, Shayoub ME, Babiker EM, et al, 2012, Effect of Ethanolic Leaf Extractnof Moringa Oleifera on Aluminium-induced Anemia in White albino Rats, Jordan Journal of Biological Science, Vo.5, pp. 255-260

13. Mun'im A, Puteri MU, Sari SP, et al, 2016, Anti Anemia Effect of Standarized Extract of Moringa oleifera Lamk Leaves on Aniline induced Rats, Pharmacognosy Journal, Vol.8, pp.255-258

14. Abramoswki SW, Waeber G, Gassner C, et al, 2014, Physiology of Iron Metabolism, Transfus Med Hemother, Vol.41(3): 213-221

15. Gallaler DD, 2017, Iron bioavalibility from Moringa oleifera leaves is very low, FASEP Juornal, abstract number : 786.13 https://www.fasebj.org/doi/abs/10.1096/fasebj.31. 1 supplement.786.13

16. Harmse L, 2016, Understanding The Management of Iron Deficiency Anemia, South African Family Practise, Vol.58, No.6, https://www.ajol.info/index.php/safp/article/view/ 149324/138823

17. Fahey JW. 2005. Moringa oleifera: A Review of the Medical Evidence for Its Nutritional, Therapeutic, and Prophylactic Properties. Part 1. Trees for Life Journal. < http://www.TFLJournal.org/article.php/20051201 $124931586>$ 